\title{
Árfo-guov'del -joiku: improvisointia vai opitun toistoa?
}

Pääongelmana aiheessani on se, kuinka luova improvisointi voidaan erottaa ulkoaopetellusta perinteen toistamisesta. Esimerkkikohteeksi olen valinnut saamelaisjoiun, jonka A.O. Väisänen nuotinsi kirjaan Lapska sånger I (Grundström-Väisänen 1958, 33). Yritän siis selvittää, onko kyseisen joiun rakenne säkeistölaulun tavoin toistuva (opittu) vaiko epäsäännöllinen, itkujen tapaan improvisoitu kuten Väisäsen nuotinnos antaa ymmärtää.

\section{Säännöllisyys - epäsäännöllisyys.}

Kun edellä yhdistin käsitteet epäsäännöllinen-improvisoitu ja säännöllinen-opittu, on taustalla oletus, että kyseisten sanaparien termit ovat keskenään suoraan verrannollisia: mitä epäsäännöllisempi rakenne, sitä enemmän improvisoitua se on. Ja toisaalta mitä säännöllisempi rakenne, sitä helpommin se on opittavissa ja sitä todennäköisemmin se on perinteen toistamista. Koska termit elävät, ovat liukuvia, sopisi välimuodoksi seuraava sääntö: mitä säännöllisempi, yksinkertaisempi improvisaation rakenne on, sitä helpommin se muuttuu perinteeksi. 


\section{Informaation määrän suhde traditioon ja luovuuteen.}

Miksi säkeistölaulun tapainen säännöllinen rakenne ja improvisointi ovat tärkeitä vastakohtia? Mm. John Blacking on tuonut esiin perinnemuusikkojen jatkuvan tarpeen kulkea vastavirtaan oman perinteensä sisällä (Blacking 1987, 55). Toistuva säkeistölaulu on tyypillinen kulttuuriperinteen edustaja. Tämä osa kulttuuria voidaan opettaa ja oppia erilaisissa opettaja-oppilas -suhteissa. Näin perinne siirtyy sukupolvelta toiselle tai paikasta toiseen. Leonard B. Meyerin mukaan kommunikaatio syntyy tyylin tuntemuksesta ja ennustettavuus on puolestaan tyylin peruskäsitteitä (Meyer 1965, 42, 55). Ja lopuksi tärkeä laajennus: kulttuuri on tyylin tavoin opittu todennäköisyysjärjestelmä (Meyer 1967, 17). Mitä todennäköisempi sanoma on, sitä vähemmän informaatiota se sisältää (Wiener 1954, 21). Kulttuuri muuttuu yhteisön jäsenelle nollainformaatioksi siinä vaiheessa, kun hän on oppimisen kautta sisäistänyt sen. Yksilö käyttää perimäänsä viestintäaineistoa joko toistaen sitä - siis ennalta-arvattavasti - tai luovasti, improvisoiden. Jälkimmäisessä tapauksessa hän hyödyntää perinteen aineksia uudessa järjestyksessä, uusina yhdistelminä tai uusissa yhteyksissä. Tällaisia ainutkertaisia yhdistelmiä käytettäessä sanoman ennalta-arvattavuus pienenee, so. sen informaatiomäärä kasvaa.

\section{Traditio ja ryhmäidentiteetti.}

Yllättävän harvat tutkijat ovat käsitelleet informaation ja sosiaalisen vuorovaikutuksen välistä kytkentää. John Blacking puhuu ryhmätietoisuudesta, joka opitaan kulttuurielämässä yhteisesti jaettujen kokemusten kautta. Yksilötietoisuus ulottuu hänen mukaansa ryhmätietoisuuden rajojen yli, kun yksilö kehittää alueita, joita hänen yhteisönsä ei ole vielä löytänyt (Blacking 1973, 113). Toista kautta lähestyy samaa asiaa Abraham Moles todetessaan, että ymmärrettävyys on kääntäen verrannollisessa suhteessa informaation määrään (Moles 1971, 81). Onhan ymmärrettävyys tiukasti sidoksissa samaistumisen ja vieraantumisen käsitteiden kanssa viestinnässä.

Tiivistän seuraavassa, mitä olen aikaisemmin kirjoittanut informaation ja identiteetin välisistä suhteista (Saastamoinen 1985, 1987, 1990). Perinteen sisältämä informaatio lähenee nollaa yhteisön jäse- 
nen opittua sen ja kyetessä toistamaan sitä. Oppimisprosessin yhteydessä syntyy yhteisön sisällä niiden ihmisten joukko, jotka sanoman alun kuultuaan - tietävät kuinka sanomaa pitää jatkaa. Slobodan mukaan on vaikea palauttaa mieleen musiikkia, joka ei sisällä tuttuja kaavioita tai rakenteita (Sloboda 1986, 5). Tämä yhteinen kokemuksellinen suhde viestiin synnyttää yhteisössä yhteenkuuluvuuden tunteen - tämän informaation suhteen. Me-henki ei siis ole jotain yleistä, vaan se on ryhmän ykseyttä siinä tilanteessa sen sanoman suhteen. Vastaavien kokemusten summa elämän eri alueilla luo yhteisön kokonaisuuden. Mikään osatekijä yksin ei riitä siihen kuin tilapäisesti. Kussakin elämäntilanteessa on kysymys subjektiivisesti esiinpulppuavista välttämättömistä ja riittävistä ehdoista, joiden perusteella viestin lähettäjä hyväksytään ryhmään kuuluvaksi. Ryhmätunne ja sen syntymisen ehdot ovat siis hyvinkin eläviä ja häilyviä.

\section{Improvisointi yksilöllisyyden mittana.}

Ryhmätunnetta vahvistavan nollainformaation sijasta improvisointi tuo esiin yksilön erottamalla hänet yhteisön jäsenistä uniikilla esityshetkellä, koska sanomassa on mukana ainutkertaista yllättävyyttä. Ei esittäjä eikä kuulija tiedä, mitä seuraava hetki tuo tullessaan. Tämä tekee esittäjästä korvaamattoman. Luova, improvisoitu musiikki on perinteen ja sitä kautta ryhmäidentiteetin vastakohta. Se nostaa luovan yksilön esiin persoonana, poikkeuksena laumasta. Sanoman sisältämä informaation, epäjärjestyksen määrä heijastaa tätä pyrkimystä joko yhteenkuuluvuuteen tai yksilöllisyyteen. Tässä mielessä improvisointi on sosiaalisen kanssakäymisen kahden olomuodon toinen ääripää.

Palvellessaan inmisten välistä kommunikointia musiikki sisältää aina kaksi puolta: nollainformaatiota edustavan tradition sekä sen tuntevien inmisten ryhmätunteen ja toisaalta kaikille suurta informaatiomäärää edustavan improvisoinnin, joka vahvistaa yksilölisyyttä. Musiikilla ei ole abstraktia itseisarvoa, vaan sen tehtävä on palvella elollisten systeemien välistä kanssakäymistä informaatioluonteensa lisäksi myös tunteita herättämällä. Tämä sisältää mahdollisuuden huomioida em. vuorovaikutuksen piiriin kuuluvaksi kaikki se mikä elää. 


\section{Musiikin assosiaatiot.}

Mitä vaikeampi teoksesta on löytää sisäistä merkitystä, sitä suuremmaksi kasvaa pyrkimys etsiä viittaavia merkityksiä. Kuulija voi kiinnittää huomionsa johonkin muuhun osatekijään tai sitten hän luopuu kokonaan yrityksestä mieltää musiikkia (Meyer 1965, 275-276).

Musiikki pyrkii olemaan viestiä inmiseltä inmiselle. Informaation lisäksi se väistämättä tuottaa ulkomusiikillisia assosiaatioita, jotka käytännössä ovat yhtä merkittävä osatekijä kuuntelukokemuksessa. Tarkoitan niitä kokemuksia, elämyksiä ja ajatuksia, jotka pulpahtavat pinnalle tietoisuuteen musiikin herättäminä yksilön omasta sisäisestä maailmasta. Kun elämys on kerran liimautunut kiinni johonkin musiikkiin, sillä on taipumus ehdollistua.

Esimerkkinä mainittakoon saamelaisten persoonajoiku, joka henkisessä todellisuudessa - tuo kyseisen henkilön "läsnäolevaksi". Ulkomusiikilliset assosiaatiot liimautuvat siis musiikkiin kiinni samoin kuin nimi liimautuu inmiseen - toistuvien kokemusten kautta. Tämä ei merkitse mitään mystistä, sillä täsmälleen sama ilmiö esiintyy myös musiikin sisällä. Itse asiassa se muodostaa musiikin viestinnän perustan. Ainoastaan kokemus liittää länsimaisen musiikin huippu- ja perussoinnut yhteenkuuluviksi. Tonaalisen harmonian teoria on itse asiassa vain todennäkäisyysjärjestelmän esitys (Meyer 1965, 54). Musiikillisella tapahtumalla on tietty merkitys vain, koska se viittaa odotettavissa olevaan toiseen musiikilliseen tapahtumaan. Koska odotukset syntyvät tyylin tuntemuksesta, on kuulijalle tuntemattomalla tyylillä esitetty musiikki merkityksetöntä (Meyer 1965, 35). Musiikillinen säännöstö syntyy siis vain kokemuksen vahvistamana. Säännöt eivät ole globaalisia - universaaleista puhumattakaan. Musiikin kaaos ja järjestys ovat tässä yhteydessa subjektiivisia käsitteitä, aina suhteessa tiettyyn kuuntelijaryhmään. Samalle musiikilliselle sanomalle voi siis olla yhtä monta eri merkitystä kuin on kuulijoita (Silbermann 1963, 6768). Jenne on määritellyt asian vielä täsmällisemmin: Mitä kompleksisempi rakenne, sitä erilaisempia ovat saman teoksen kuuntelukokemukset (Jenne 1984, 98). Sanoma vaikuttaa satunnaiselta, kunnes löytyy koodi lukea sitä (Jauch 1973, 63-65). 


\section{Säveltäminen ja improvisointi.}

Eikö "kaaoottinen" sävellyskin täytä kaikkia improvisoinnin tunnusmerkkejä? Epäjärjestys sinänsä ei ole riittävä ehto sille, että jokin voidaan määritellä improvisaatioksi. Sävellys on toistettavissa mutta improvisaatio on ainutkertainen. Jos se tavalla tai toisella toistetaan sellaisenaan, se ei enää ole improvisaatio vaan sävellyksen esittäminen. Improvisaatio voidaan säveltää vain esitystilanteessa ja se on ainutkertainen, peruuttamaton. Sitä ei voi korjata uusimalla, vaan se korjaa itse itseään esityshetkellä esimerkiksi luomalla virhepoikkeamasta säännön, uuden toistuvan rakenneosan. Tämä selittää osan rakenteiden monimutkaisuudesta.

Musiikkiesityksen mahdollinen ainutkertaisuus voidaan määritellä vasta analysoimalla useita kyseisen teoksen esityskertoja. Jatkuva muuntuminen on yksi improvisaation tunnusmerkeistä. Tavallisesti tarvitaan lisäksi ulkomusiikillisten faktojen - esityskäytännön ja yleisen kulttuuritradition - tuntemista. IIman näitä tietoja pelkkä yksityisen teoksen analyysi on riittämätön selvittämään varmuudella jonkin teoksen mahdollista improvisoinnin astetta. Viitekehystietojen puutteessa voidaan ainoastaan esittää todennäköisyysarveluja esimerkiksi siitä, onko yleensä motivoitua opetella ulkoa sellaista, jonka sisäinen epäjärjestys tuntuu inhimillisen mittapuun mukaan ylivoimaiselta ulkoaopittavaksi kyseisen kulttuurin sisällä. Asiaa valottaa vertaus musiikista pelinä: ei ole mielekästä opetella vaikkapa jotain jalkapalloottelua ulkoa. Mieltä on vain pelissä käytettyjen osasuoritusten harjoittelussa. Tätä materiaalia voidaan sitten käyttää luovalla tavalla seuraavissa peleissä.

\section{Improvisoinnin peliluonne.}

Puhuimme jo aikaisemmin kuulijan aktiivisesta osuudesta esityksen sanoman jälleenkoodaamisessa. Blackingin mukaan jokainen esitys voi olla luova kokemus kaikille asianosaisille, koska esittäjän ja yleisön on yhtälailla luotava se sisällään uudestaan (Blacking 1987, 19). Ja edelleen: esittäjien ja kuulijoiden on harjoiteltava musiikkia siinä missä alkuperäisten tekijöidenkin. Kuunteleminen on yhtä paljon esittämistä kuin laulaminen ja soittaminen (Blacking 1987, 123-127). 
Kun musiikki-improvisaatioita verrataan peleihin, tapahtuu vertailu informaation peruskäsitteiden tasolla. Kysymys on ennaltaarvattavuudesta ja ennalta-arvaamattomuudesta. Peleissä on kysymys erityisesti noiden termien epäsäännöllisestä vuorottelusta erilaisten kuulijoiden mielenkiinnon ylläpitämiseksi. Jotta vastapeluria voidaan harhauttaa, on ensin luotava sääntö, josta sitten poiketaan mahdollisimman yllättävällä hetkellä. Täysin kaoottisesta toiminnasta on tuloksena tasapeli ilman kummankaan osapuolen persoonallista vaikutusmahdollisuutta. Lähellä tasapeliä pysyttelevä tilanne on kuitenkin molemmille osapuolille kaikkein kiinnostavin. Tällöin on samantekevää, onko kysymyksessä pallottelu, kielenkäyttö tai musiikillinen arvausleikki. Aivofysiologi Matti Bergströmin mukaan hermoston informaatiokapasiteetti on suurimmillaan keskimääräisissä aivojen ärsytystiloissa. Jos aisteihin kohdistuva energiapaine on pieni kuten yksitoikkoisessa ympäristössä, ovat aivojen tiedonsiirto- ja käsittelyresurssit pienet. Pienet ne ovat myös esimerkiksi melussa ja muissa ylikiihoittavissa ymp̣äristötiloissa (Bergström 1979, 125). Suhde ei välttämättä ole 1:1. On esitetty ihannetilaksi jotakuinkin suhdetta 1:2, jolloin kolmasosa viestistä edustaisi uutta ja loput tuttua. Lisään joukkoon ajatusleikin kultaisesta leikkauksesta: Koko viestin suhde traditio-osaan on sama kuin tradition suhde luovuuteen.

Improvisaatioiden rakenneanalyysit osoittavat sangen usein osatekijöiden suhtautuvan toisiinsa yksinkertaisten murtolukujen $(1: 1,1: 2$, 1:3, 1:4 ja 2:3) tavoin. Siitä huolimatta osatekijöiden esiintymisjärjestys on yksityistapauksissa merkittävältä osalta ennaltaarvaamaton. Tällaisia rakenteita ei ole mielekästä opetella ulkoa. Tässä rajamaastossa säkeistölaulun kaltainen tiukka perinne korvataan improvisoinnilla. Tyypillisimmissä tapauksissa nämä kaoottisilta näyttävät rakenteet osoittautuvat usein rakenteiltaan symmetrisiksi, joskus sarjallisuuden ja symmetrisyyden epäsäännölliseksi vuorotteluksi ja joskus mainittujen tekijöiden limittäin oleviksi kerrostumiksi.

\section{Analyysi.}

Lapska sånger -kirjan esipuheessa todetaan, että A. 0. Väisänen on tehnyt käsikirjoituksiinsa myös rakenneanalyysejä. Ainakaan Árfojoiun osalta se ei näytä edes todennäköiselta, sillä nuotinnos on tehty 
"rivit täyteen" -periaatteella ilman säkeistömuotoon viittaavia merkintöjä. Esitys vaikuttaakin aluksi improvisoidulta. Pelkän kuuntelunkin perusteella päätelmä on väistämättä sama. Huomion kiinnittyessä korkeiden $\left(A-A^{b}-G\right)$ ja matalien $(D)$ sävelten vaihteluihin huomataan välittömästi pituuserot peräkkäisten matalien sävelten sarjoissa.

Kuvassa 2 olen tehnyt melodia- ja rytmianalyysiin perustuvan uuden nuotinnoksen, jossa samantyyppiset ilmiöt on pyritty sijoittamaan päällekkäin pystysuunnassa. Sen perusteella voidaan uudelleen tutkia rytmiikkaa, melodiaa, korusäveliä (niekkuja) sekä myöhemmin myös tekstiä.

Kuva 1.

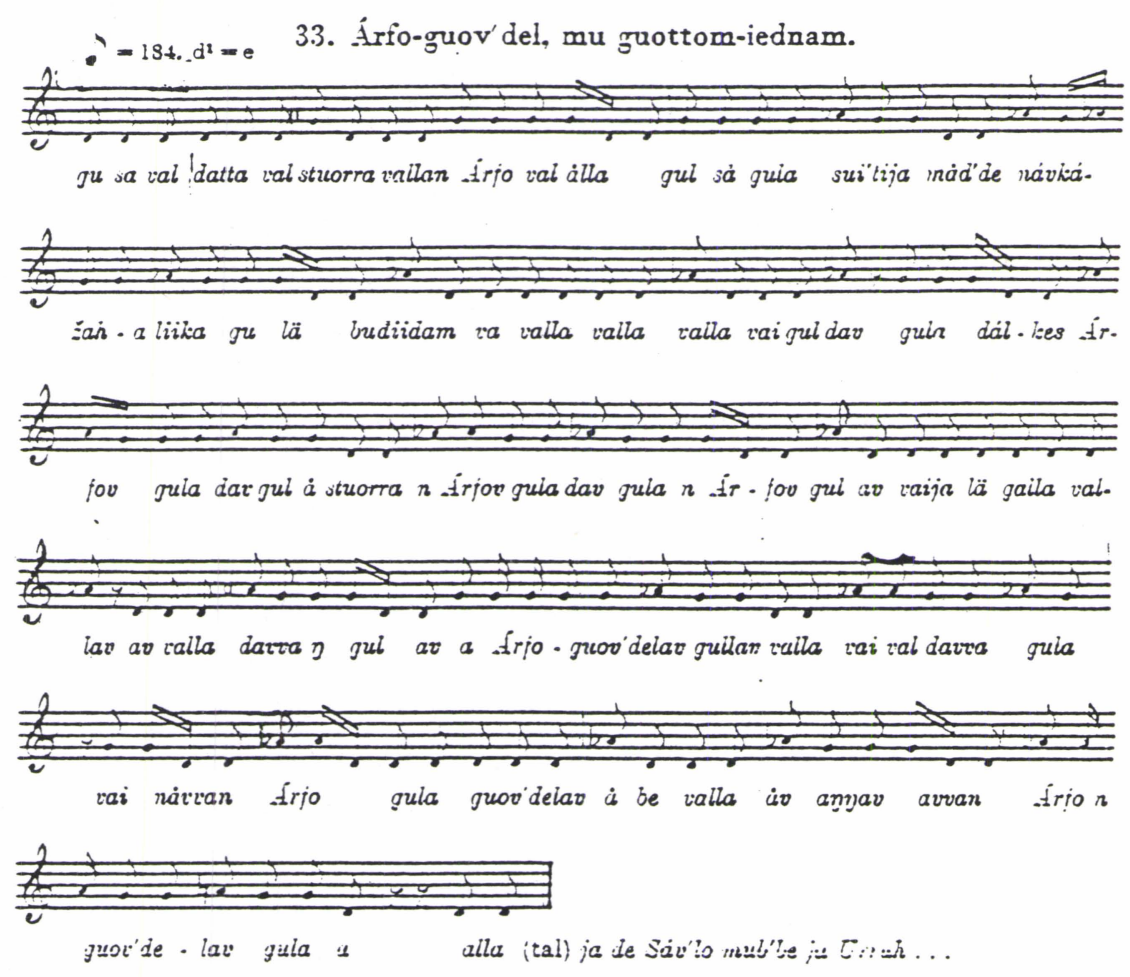


Kuva 2.
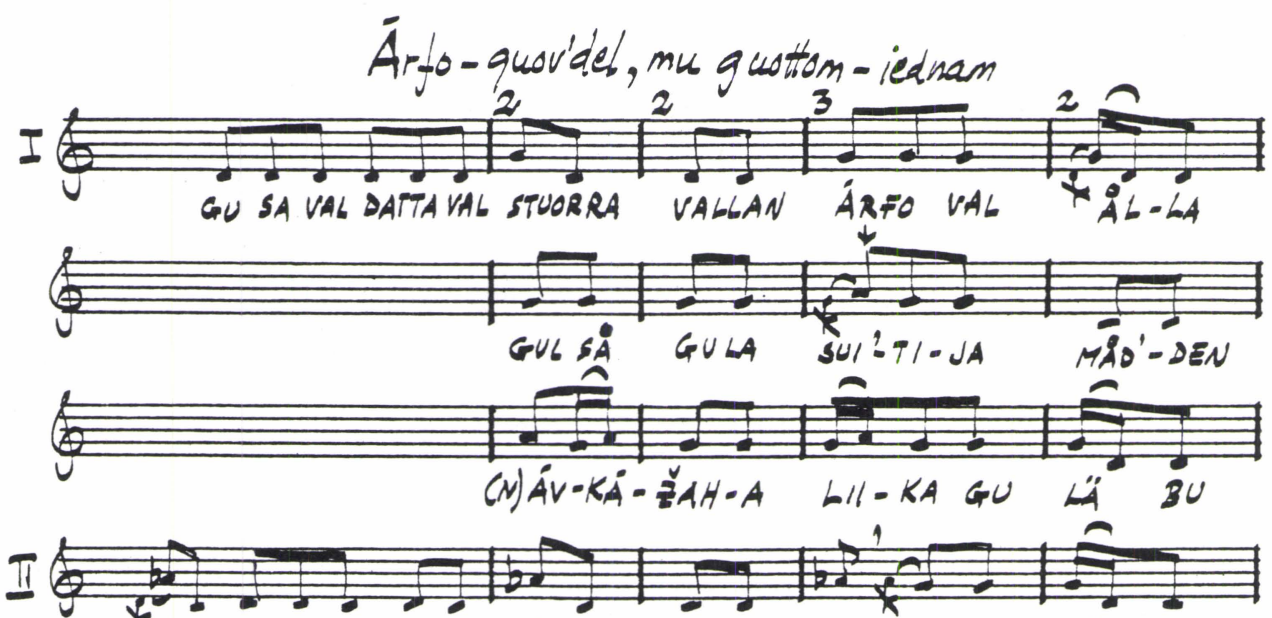

$\rightarrow$ K-DAM VA VALLIA VALILA VAL.LA VAI GUL DAV, GU.LA DÁL-KES

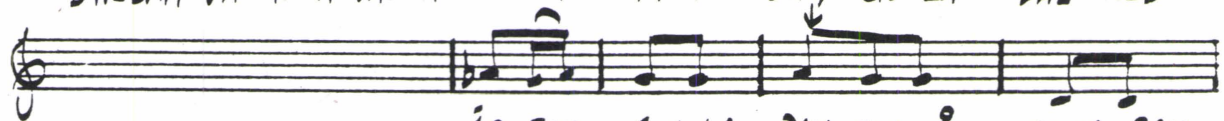

AR.FOV GUVA DAV GUL A STUOR. RAN

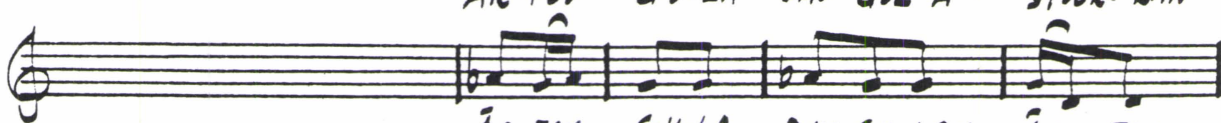
ÁR.FOV GU.LA DAV GU.LAN AR: FOV

III 20:

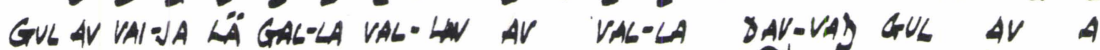
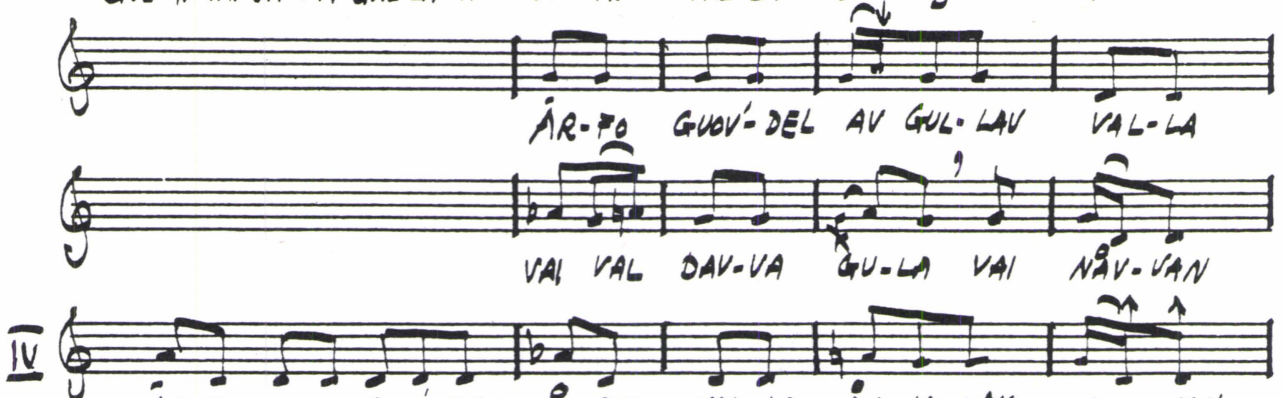
AR.FO GULLA GUOVDSELAV A BE VAL-LA AV AD-NLV AV-VAN.

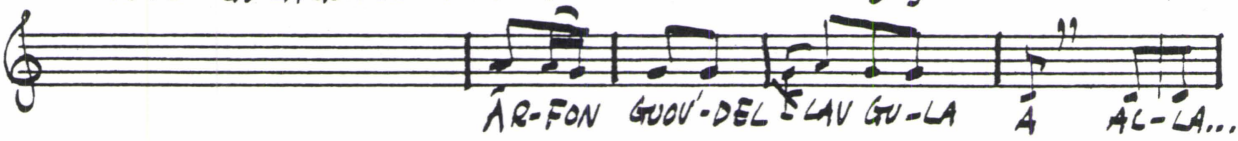




\section{Rytmiikka.}

Informaatioteorian kannalta katsottuna melodisen sanoman ajalliset hahmot ovat yhtä merkittäviä kuin sävelkorkeuksiin liittyvät hahmot (Moles 1971, 57). Tämä ei suinkaan ole vallitseva käsitys länsimaisten musiikkiesteetikkojen piirissä: "...rytmin vaihteleva metriikka... ei sellaisenaan vastaa toimikunnan ratkaisuissaan noudattamaa kompleksisuuskäsitystä" (TEOSTOn genretoimikunnan kirje tekijälle 1.2.1989). Täysin päinvastaiseen käsitykseen olen tullut mm. leu'dd- ja yukamusiikkianalyyseissäni (Saastamoinen 1987 ja 1990/2).

Analyysinuotinnoksen avulla alta paljastuu erikoislaatuinen säkeistömuoto. Jokaisen neljän säkeistön alussa on eripituinen lyhyt johdantotahti jota seuraa varsinainen kolmirivinen säkeistö, jossa yhden rivin iskualasarja on 2/8-2/8-3/8-2/8. Neljäs säkeistö näyttää jäävän "kesken" - jatkuakseen mahdollisesti seuraavalla esityskerralla. Oheinen nuotinnos eroaa Väisäsen nuotinnoksesta tahtilajimäärittelyn lisäksi siinä, että 1/8-hengitystauot olen korvannut heittomerkeillä. Mielestäni hengitystauot eivät tässä tapauksessa ole oleellinen musiikin rakennetekijä. Hengitystauot vaihtelevat säkeistöjen sisällä eri paikoissa. Jos ne huomioidaan taukoina, rakenteesta tulee kaoottinen. Jos ne unohdetaan, säkeistömuoto kristallisoituu mainituksi iskualasarjaksi.

Käytän tahtiviivoja oheisessa nuotinnoksessa melodian hahmottamiseen siten, että tahtiviivat on merkitty a) suurimpien melodisten muutosten kohdalle, b) tavuvälien sijasta sanaväleihin sikäli kuin alkuperäistekstiin on luottaminen ja c) korostamaan sekatahtilajisuutta, joka syntyy subjektiivisessa kuuntelukokemuksessa mutta joka on välttämätön tapa hahmottaa säkeistö ulkoaopeteltavaksi. Sekatahtilajisuus on sitäpaitsi tyypillinen piirre saamelaismusiikin tietyillä alueilla (Saastamoinen 1985, N:ot 126-143).

Saamelaismusiikin sekatahtilajisuus ei ole perinneajatteluun pohjautuvaa tietoista musiikin teoriaa kuten esim. Balkanin kansanmusiikissa. Se on länsimaisen ihmisen keino saada kyseinen musiikki tältä osin opeteltavissa olevaan muotoon. Tietoisen teorian sijasta saamelaiset itse toteuttavat rytmejään "kantapään kautta" opettelemalla. He kasvavat kiinni joikujen rytmeihin loputtomalla toistamisella - pikemminkin alitajuisesti kuin älyllisen pohdinnan kautta. Tahtiviivat ovat tässä siis subjektiivinen, synteettinen lähestymistapa, joka valottaa tiettyjä osatekijöitä, mutta samalla saattaa peittää esimerkiksi tekstianalyysiä. 


\section{Rytminen muuntelu.}

Kunkin säkeistön johdantotahdissa tahtilajisuhteet nähdään selvimmin, kun ne muutetaan numerosarjoiksi:

$$
\begin{aligned}
& 6 / 8(3-3) \\
& 7 / 8(2-3-2) \\
& 8 / 8(2-3-3) \\
& 7 / 8(2-2-3) .
\end{aligned}
$$

Sarja sisältää mikrorakenteeltaan epäsäännöllisen mutta ulkoasultaan symmetrisesti laajenevan ja supistuvan sarjan, joka symmetrian osalta jää loppupäästä vajaaksi 6/8:n osalta. Kaksi- ja kolmijakoisten iskualojen yhteispituuksia vertailtaessa saadaan tulokseksi: $6 \times 3 / 8=18 / 8$ ja $5 \times 2 / 8=10 / 8$. Suhde on suunnilleen $2: 1$.

Itse säkeistössä yhden säerivin iskualasarja oli siis 2-2-3-2. Kolmen säerivin yhteistulokseksi saadaan $9 \times 2 / 8=18 / 8$ ja $3 \times 3 / 8$ 9/8 Suhde on tarkalleen 2:1. Johdantotahtien yhteispituuden ja yhden säkeistön pituuden suhteet - myöskin iskualasuhteet huomioiden ovat sangen lähellä toisiaan. On huomattava, että kaksi- ja kolmijakoisten iskualojen suhde on käänteinen: Johdantotahtien 3/8 iskualojen yhteispituus $18 / 8$ on sama kuin yhden säkeistön $2 / 8$ iskualojen yhteispituus $18 / 8$. Toisaalta johdantotahtien $2 / 8$-iskualojen yhteispituus $10 / 8$ on sama kuin yhden säkeistön $3 / 8$-iskualojen yhteispituus $9 / 8$. Johdantotahtien yhteispituus $28 / 8$ on siis sama kuin yhden säkeistön pituus $27 / 8$. Jos tähän lisätään säkeistöön kuuluva keskimääräinen 1/8 -hengitystauko, on tulos täsmälleen $28 / 8$ !

Johdantotahtien rytmiset rakenteet ja pituuksien vaihtelut ovat tyypillisiä improvisoidulle musiikille. Tämä seikka ei kuitenkaan yksin riitä yksiselitteisesti osoittamaan, että ne olisivat täysin improvisoituja. Vielä epätodennäköisempää kuitenkin on, että säkeistölaulu sisältäisi tällaisia rakenteita, varsinkin kun itse säkeistöt ovat selkeästi samanlaisina toistuvia.

\section{Niekut.}

Kuvan 3 esittämässä numerosarjassa numero (1) tarkoittaa niekkua ja (O) korusäveletöntä nuottia. 
Kun tarkastellaan ensiksi numerotaulukon pystysuoria rivejä, huomataan, että A-rivi on selkeästi epäsäännöllinen. Itse säkeistöjen sisällä rivi $C$ muodostaa jatkuvan nollasarjan, kun taas rivi $E$ on symmetrinen 101-101-101-10... B-rivissä I ja III säkeistöt ovat identtiset (001) ja sama pätee puolestaan II ja IV säkeistöihin (011-01...). I ja II säkeistöjen numerosarjat ovat sitäpaitsi käänteisiä toisiinsa nähden (OOI-O11). Rivi D on poikkeuksellinen. Siinäkin I ja III säkeistöt ovat identtiset ja I sekä II säkeistöt käänteisiä (011-100) - mutta päinvastoin kuin B-rivissä. Sen sijaan kysymysmerkiksi jää D-rivin IV säkeistö. Kahden alkusäkeen 01 -sarja onkin käänteinen II säkeistön vastaaviin numeroihin (10). Kun johdantotahdit jätetään huomioimatta ovat I ja III sekä toisaalta II ja IV säkeistöt keskenään identtiset parit viimemainittua poikkeusta lukuunottamatta.

Kuva 3

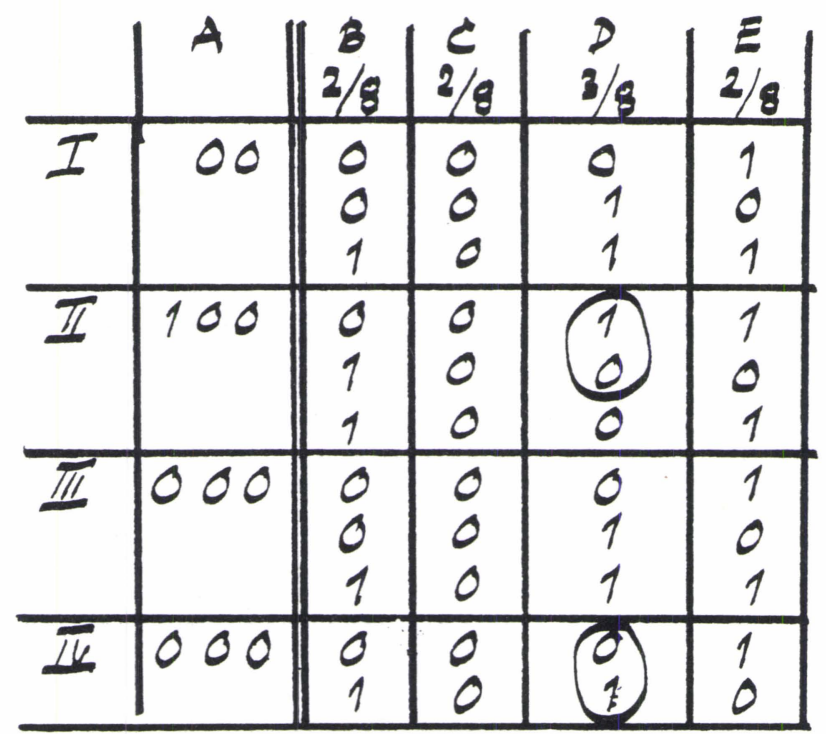

Niekullisten ja niekuttomien iskualojen suhde pystysuorissa riveissä on seuraava (l:O): $A=1: 10, B=5: 6, C=0: 11, D=6: 5, E=7: 4$. Alueella $B-E$ kokonaissuhde on siis $18: 26=2: 3$ ja koko esityksen puitteissa suhde on 19:36=1:2. Kun vertaamme säerivejä keskenään, on tuloksena I riviltä (ilman johdantotahteja) $5: 11=1: 2$, II riviltä $5: 11=1: 2$ ja III riviltä $8: 4=2: 1$. On tärkeää huomata, että johdantotahtien mukanaolo on tärkeää kokonaissuhteiden tasapainolle, joka muistuttaa suuresti impro- 
visaatioiden rakenteille tyypillisiä peruspiirteitä. Niekkujen rakennekaavio säkeistöittäin (ABAB) muistuttaa ennaltasuunniteltuja rakenteita, mutta johdantotahdit ja IV säkeistön lopun poikkeukset huomioonottaen tuntuu lähes uskomattomalta, että saamelaiskulttuurissa olisi vaivauduttu turvautumaan noin kompleksisen kokonaisuuden ulkoaopettelemiseen improvisoinnin sijasta.

\section{Sävelkorkeudet.}

Äänitenauhalla ilmenevä sävelkorkeuden portaaton nousu vaikeuttaa tuntuvasti yksityisen sävelkorkeuden täsmällistä tulkintaa. Koska tässä suhteessa Väisäsen nuotinnos poikkeaa omastani, jätän sävelten A$A^{b}-G$ väliset mikroerot kokonaan analyysin ulkopuolelle. Sen sijaan yleinen "korkean" ja "matalan" sävelen välinen ero on ratkaiseva pohdittaessa, onko kysymyksessä improvisointi vai säkeistöjoiku.

Kuva 4.

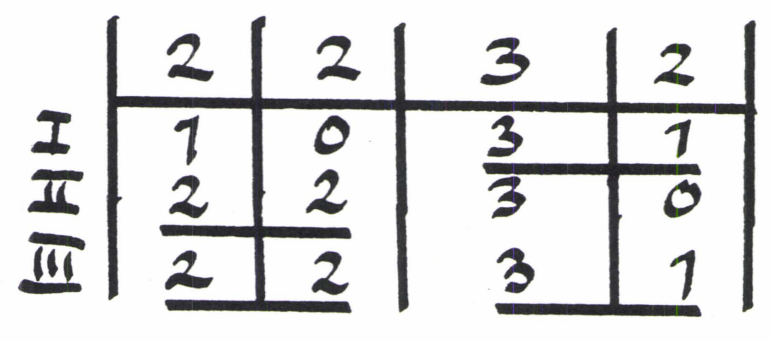

Kuvassa 4 sävelkorkeuserot on muutettu jälleen numerosarjaksi siten, että yhden säkeistön kolme kertaa toistuvassa iskualasarjassa 2-2-32 korkeiden sävelten esiintymismäärät on merkitty numeroilla. Tuloksena on taulukko, jossa I ja III rivien lopussa esiintyvä niekku on tulkittu korkeaksi säveleksi. Säkeistömuoto on ilmiselvä, mutta sen sijaan säkeistön sisärakenne kompleksinen. II ja III rivien alut ovat identtiset kuten myös I ja III rivien loput (3-1). Korkeiden äänten osuus lisääntyy rivi riviltä sarjana $5-7-8=20$, kun taas matalien äänten osuus vähenee sarjana $4-2-1=7$. Säkeistön sisällä suhde on $20: 7=3: 1$. Koko esitys huomioonottaen korkeiden äänten suhde mataliin on $75: 53=3: 2$, koska johdantotahtien matalat äänet tasoittavat 
tilanteen. Edelleen tässä ilmenevät murtolukusuhteet ovat hämmästyttävän yksinkertaisia mutta samalla tarkkoja.

Sama sävelsuhdekaavio toistuu tarkasti säkeistöstä toiseen. Improvisoivan inmisen tehtävä ei ole sokeasti totella mekaanisia sääntöjä vaan paeta niitä poikkeuksia luomalla. Tässä tapauksessa edessämme on erittäin kurinalainen ennaltaopeteltu tuote melodian yleiskaaren suhteen. (Vain johdantotahtien ja niekkujen osalta se hyvinkin voisi olla improvisoitu.) Jos pitäisimme sitä improvisoituna, pitäisi esittäjän muistaa yhdellä hetkellä luotu sävelkorkeuksien monimutkainen kaavio kertakuulemalta ulkoa. Ajatus vaikuttaa mahdottomalta. Se mikä alussa vaikutti kaoottiselta epäjärjestykseltä Väisäsen nuotinnoksen perusteella, osoittautuu lopulta ulkoaopittavaksi säkeistömuodoksi, jossa mahdollisella improvisoinnilla on selkeät rajansa. On kokonaan toinen asia, ettei tällaisia säkeistörakenteita löydy koulujen oppikirjoista.

\section{Lauluteksti.}

Nojaudun tekstianalyysissä täysin Väisäsen nuotinnoksessa olevaan kirjoitustapaan, koska en itse tunne kieltä. Lähtökohtana tekstianalyysissä on sama periaate kuin musiikissa: verrata samankaltaisia sanoja ja tavuja keskenään ilman sanojen merkityssisältöä sekä tutkia niiden järjestystä, epäjärjestystä sekä esiintymismäärien tilastollisia suhteita yleisten improvisointianalyysien tavoin.

Kuvassa 5 on esitelty pelkkä teksti - samoin säkeistöittäin aseteltuna kuin kuvassa 2 . Kohdat A-D esittelevät samantyyppisten sanojen ja tavujen esiintymisen tekstissä siten, että kokonaisluvut ilmaisevat kaksitavuisten sanojen määrän ja murtoluvut puolestaan yksityisten tavujen esiintymisen. Oikean reunan pystysuoralla rivillä nämä on laskettu yhteen, koska joukossa on tuntematon määrä merkityksettömiä täytetavuja. Kuvasta kannattaa panna merkille ainakin seuraavia seikkoja:

1) Alleviivaamattomien sanojen/tavujen määrä $(E)$ on sama kuin kohdissa $B$ ja $C$ tai $A+D(15-171 / 2)$. Epätarkkuus syntyy siitä, että joidenkin sanojen tavut muistuttavat itsenäisiä irtotavuja.

2) $A+D$ on sama kuin $B, C$ tai $E$. Jokainen näistä muodostaa suunnilleen neljäsosan kokonaisuudesta. 


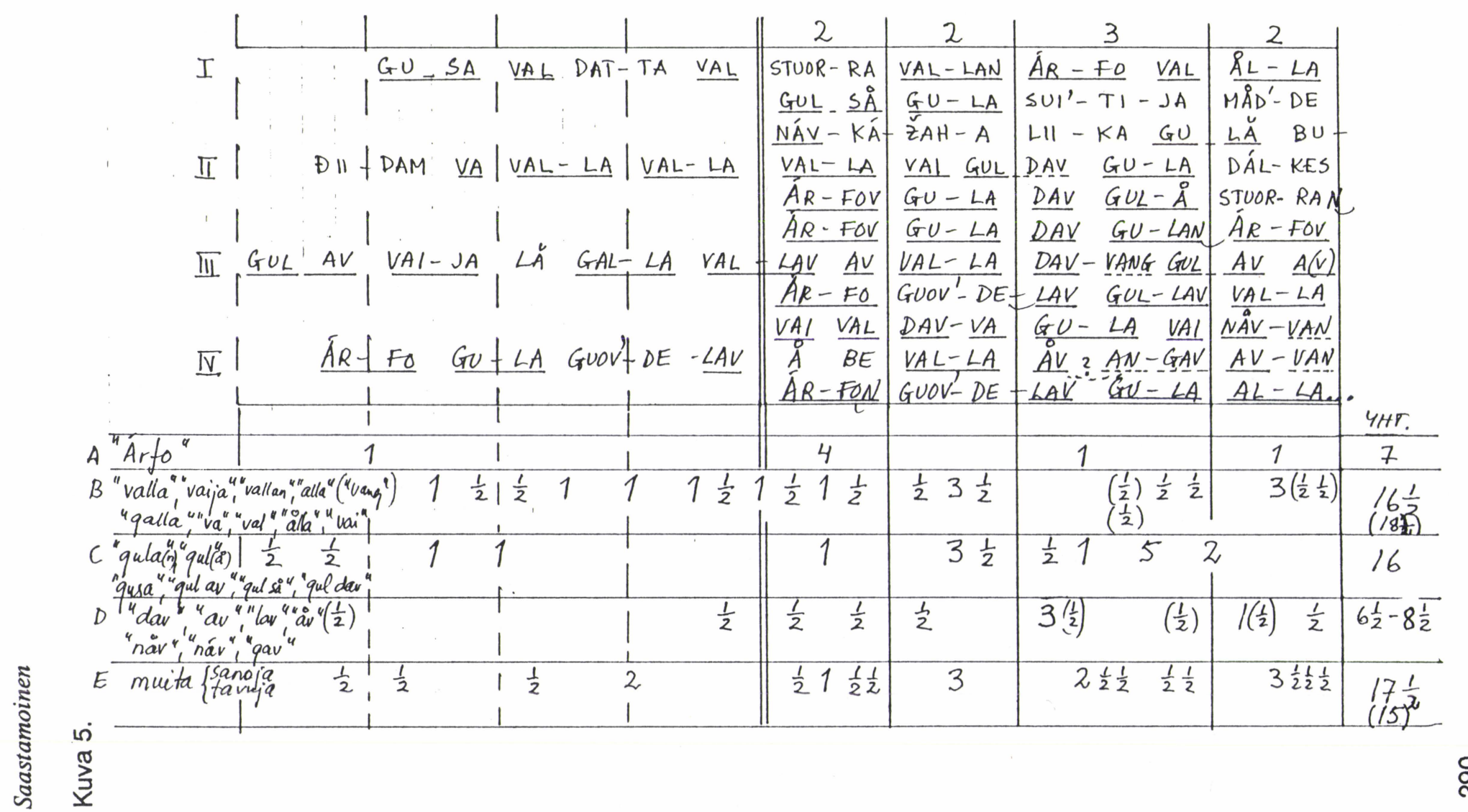


3) $A: B: C: D: E$ on suunnilleen 1:2:2:1:2. Esiintymismäärien suhde muistuttaa selkeästi improvisaatioiden yleistä rakennemallia yksinkertaisia murtolukusuhteita.

4) Sanojen tai tavujen ennalta-arvattavuus on erittäin pieni esim. vertailtaessa avainsanojen A, B ja C esiintymisjärjestystä.

5) Sisältä löytyy myös muuntelevaa toistuvuutta, jos verrataan keskenään rivejä II/2-3, III/2, IV/ johdantotahti ja II rivi. Nämä viisi katkelmaa muodostavat suunnilleen kolmasosan $(5 / 15)$ koko tekstistä.

Edelläolevasta selviää, että teksti puolestaan täyttää useita tyypillisiä improvisaation tunnusmerkkejä: säännön ja poikkeuksen välinen tasapaino, yksityisten ilmiöiden ennalta-arvaamattomuus, toistuvuuden ja ainutkertaisuuden epäsäännöllinen vuorottelu (erityisesti kohdassa 5) sekä osatekijöiden väliset yksinkertaiset murtolukusuhteet. Kuka onkaan se nero, joka olisi kyennyt "runoilemaan" näin monikerroksellisen tekstin?

Improvisoinnin perusperiaatteita on sääntöjen noudattamisen sijasta tuottaa epäjärjestystä - säännöllisyyden ja epäsäännöllisyyden ennalta-arvaamatonta vuorottelua. Tekstin osalta Árfo-joiku täyttää täydellisesti tämän tunnusmerkin. Se on alitajunnasta pulppuavaa sanojen leikkiä, sääntöjen jatkuvaa pakenemista. Lopputuloksena näemme otteen mahdollisesti iltapäiväänsä elävästä musiikkikulttuurista. Samanlaisen ilmiön olemme jo todistaneet kalevalaisen runolaulun viimeisessä vaiheessa: teksti on improvisoitua, mutta se on suljettu tiukaksi kivettyneeseen musiikilliseen pakettiin - meidän tapauksessamme säännölliseen 5/4 -tahtilajiin. Musiikkia voi tässä tapauksessa nimittää pikemminkin melodian tulkinnaksi kuin improvisoinniksi. Vain tulevaisuus näyttää, käykö saamelaisjoiulle kuten meidän runolaulullemme, vai syntyykö se maailmanmusiikki-ilmiön myötä Fenixlinnun tavoin - ensin kuitenkin länsimaisuuden tulessa poltettuna.

\section{Lähteet.}

Bergström, Matti (1979), Aivojen fysiologiasta ja psyykestä. WSOY. Blacking, John (1973), How musical is man? University of Washington Press.

Blacking, John (1987), A commonsense view of all music. Cambridge University Press. 
Grundström-Väisänen (1958), Lapska sånger I. Uppsala. Jauch, J.M. (1973), Are quanta real? Indiana University Press. Jenne, Michael (1984), Music, Communication, Ideology. Birch Tree Group, Princeton.

Meyer, Leonard B. (1965), Emotion and meaning in Music. Univ. of Chicago Press, 1956, 7. painos.

Meyer, Leonard B. (1967), Music, Arts and Ideas. Univ. of Chicago Press.

Moles, Abraham A. (1971), Informationstheorie und ästetische Wahrnehmung. M. DuMont Schauberg, Köln.

Saastamoinen, Ilpo (1985), Kansat soittavat - alkumusiikin lähteillä. Tammi.

Saastamoinen, Ilpo (1987), Kolttasaamelainen leu'dd. Etnomusikologian vuosikirja 1986.

Saastamoinen, Ilpo (1990/a), Keiteleen oudompi nuottikirja. Tampereen yliopisto, Kansanperinteen laitos.

Saastamoinen, Ilpo (1990/b), Tupakkapeltojen kuumat rummut. Musiikin suunta 2.

Silbermann, Alphons (1963), The sociology of music. Routledge and Regan Paul, London.

Sloboda, John A. (1986), The musical mind. Oxford Univ. Press Wiener, Norbert (1954), The human use of human beings. Doubleday Anchor Books, N.Y. 